\title{
Comprehension of the Principle of Good Administration in the Framework of EU Administrative Law
}

\author{
Areean Mustafa \\ University of Human Development-Iraq
}

\begin{abstract}
Good administration is a European administrative principle that could be deemed as an instrument for enhancing transparency, legal certainty and predictability in administrative procedures. There is no certain definition for the principle. The definitions differ depending on the disparity of the viewpoints. Charter of Fundamental Right of the European Union classifies the principle as one of the fundamental rights of individuals, while the European Union's Courts differentiate between the various sub-components of the principle to establish a comprehension for their characteristics. The current article suggests that the principle could be understood from both sides, although perceiving it as a fundamental right would more reasonably establish a stronger protection for the individuals in their contact with the administrative institutions; as the individuals' rights are now more central in the modern administrative systems around the globe.
\end{abstract}

Index Terms - good administration, principle of care, right to be heard, obligation to state reason, fundamental rights, administrative standards, charter of fundamental rights of the European Union, EU case-law.

\section{INTRODUCTION}

$\mathrm{S}$ INCE the last decades of the $20^{\text {th }}$ century, two parallel discourses appeared in the administrative policy debate: New Public Management and the concept of Good Governance. The two discourses are reminiscent of the classical couple concepts efficiency and legal certainty that have guided the administrative law for almost a century. We cannot keep ourselves aloof the constant force balances between these values, and it should be emphasized that it is not always the matter of the conflicting interests. The individuals' legal rights include the requirement of taking decisions by the administrative authorities, inter alia, efficiently and within a plausible time. Furthermore, the efficiency in the administrative decisions and procedures is

Areean Mustafa is an assistant lecturer in Public Law at the College of Administration and Economics, University of Human Development- Iraq. He received B.Sc. in Law at University of Sulaimani-Iraq, 2003, and LL.M (Eur) at Södertörn University- Sweden, 2012. His research interests are; Administrative Law, EU Law, Migration Law, Commercial Law and Competition Law.

Email: areean.mustafa@uhd.edu.iq or areeanmustafa@ gmail.com. not aimed only on economic efficiency but also requires substantial achievement or quality of decision making [1].

Good administration, which is mostly invoked as a European law concept, could be deemed as a part of a more comprehensive concept of good governance which has been encompassed by the EU relying on the principles of a democratic society based on the rule of law and effective European policy [2].

However, there is no unanimous definition for the concept of good administration in EU law. Defining good administration varies depending on variation of perspectives. From one point of view good administration is considered as a fundamental right for individuals in their relationship with administrative authorities, whilst from another perspective the concept might be defined as an administrative obligation, requirement or standard for public authorities to take appropriate measures in the administrative matters.

This study tries to discuss and analyze the abovementioned approaches for the purpose of shaping a comprehensive understanding of the notion of good administration in the context of EU administrative law.

The scope of this article is limited to three eminent administrative procedural principles, namely principle of care or due diligence, right to be heard and the obligation to state reason, which will be discussed and analyzed within the European Union administrative law framework. Moreover, this framework-demarcation requires that all other legislation and case law which fall into the context of other European bodies outside the EU, and also those documents and case-law which apply to the European states as sovereign states, will be excluded from this study.

Direct after this introductory part, we go through the notion and perception of good administration in EU in general, then in various European documents with focusing on the most significant documents in that regard. Afterwards the rise and development of the notion in the Charter of Fundamental Rights and EU case law will be explained, discussed and analyzed. All these will be followed by a brief conclusion in 
which we try to sum up the most widely used and comprehended form of the concept of good administration in the EU legal scope.

\section{THE NOTION OF GOOD ADMINISTRATION}

The concept of good administration, or sound administration, is used in the context of public authorities' activities. Good administration means the way in which administrative authorities work [3]. Recognition of the principle of good administration aims to legally protect individuals in their contact with public authorities. This leads consequently to an open, secure and predictable administrative procedure [4]. Generally, good administration is mostly invoked in the context of the procedural rules which would be established within an administrative law framework.

Good administration in the broader context can, however, mean that the administration is perceived as legitimate, as long as its administrative actions have been efficient not only from its procedural side, but they would be correct even in its material aspect [5]. Thus good administration could be deemed as an umbrella concept which might be incorporated into the substantive as well as the procedural principles of administrative law. As Nehl states, the notion of good administration in the broad meaning is nothing but "an aid to describing the corpus of the continuously evolving- legally enforceable and unenforceable-procedural and substantive requirements with which a modern administration has to comply." [6].

An appropriate system of administrative procedures warrants the legitimacy and also the quality of administrative decisions; it also ensures citizens' rights and encourages citizens' contribution. Moreover, good administration enhances transparency and accountability by evading unreasonably complicated, formalistic and long-lasting procedures. Good Administration functions, thus, toward promoting social faith in the executive power which could result in political and social stability [7].

As mentioned in the introductory part, there are three prominent procedural principles which have been strongly associated with the concept of good administration in an administrative law context, in the sense that they are overwhelmingly deemed as the most essential components of the general- or the umbrella principle of good administration.

To be stated very briefly, the first procedural principle which is invoked widely in the context of good administration is known as the Principle of Care or Due Diligence as a principle of administrative law which imposes requirements on the administrative authorities to achieve an impartial and careful handling in the administrative cases, and consequently hinders the authorities from taking irresponsible and wrong decisions that could damage the interests of individuals in administrative proceedings [8]. A careful processing can be achieved through an adequate and proper investigation and by a good administrative service. The principle of Care can thus be understood in the context of both the duty to investigate[8] as well as the public service obligation[9]. The principle can be considered to include also the obligation to act in a reasonable time [10].

The second principle is the Right to be heard which means that a person whose interests are adversely affected by a decision taken by a public authority must be given the opportunity to comment before the decision is taken [11]. The principle seems to be an administrative interpretation of a significant principle in criminal law; that no one shall be convicted unheard. It can moreover be interpreted in the light of the principle of good administration in the sense that the law guarantees individuals the right to have visibility into - and also affect the administrative authorities' investigations and decisions in their cases [12].

And finally the third principle is the public authorities' obligation to state reason for their decisions. This principle covers a broad area; it includes both administrative decisions and legislative acts [13]. Regarding legislative acts, the principle demands that the legislator should state the legal grounds for legislation, while the obligation to state reasons in administrative decisions involve interpretation and application of the law, on which the decision was based, must be stated [14]. The principle might be interpreted against the background of transparency [13], which means that everyone shall have the right to understand their legal position after the decision-making or law-making. In terms of administrative law, the principle is an important prerequisite for creating convictions of individuals on the legality and appropriateness of implemented administrative measures. It also offers a guarantee for the individual that the authority has selected the best possible solution to solve the current issue in the case. It may further reduce the scope for discretion in which there is often a risk for abuse of power [15]. It is also linked to the right of effective judicial protection in a manner that a decision must be justified in order to be challenged by the individual which adversely affected by the decision ${ }^{1}[16]$.

\section{THE GENERAL PRINCIPLES OF LAW, THE FUNDAMENTAL RIGHTS AND GOOD ADMINISTRATION}

EU law has been built on a number of principles that formulate and regulate both legislative and administrative actions of the Union. The general principles constitute binding legal sources in the EU [17]. They are binding not only for the EU institutions, but also for Member States during implementing EU law [18]. In other words, national authorities and courts in the Member States are obliged, in

\footnotetext{
${ }^{1}$ European Court of Justice in its judgment in case 222/86 Heylens 1987 established the link between the two principles. See the referred case, para. 15.
} 
each case they implement Union law, to take into account observance of the general principles of law [10].

A number of general principles have been expressly raised in the Union treaties, such as the principle of loyalty (art. 4.3 TEU) ${ }^{1}$, subsidiarity and proportionality (art.5 TEU), the principle of legality (art. 13.2 TEU), the principle of equality (art. $18 \mathrm{TFEU}^{2}$ and the principle of transparency (art. 15 TFEU). In addition, art. 6.3 TEU states that fundamental rights, in the sense that have been set out in the $\mathrm{ECHR}^{3}$ and which come from the Member States' common constitutional traditions, to be regarded as general principles of EU law, while other principles of law which are not expressed in the Treaties have been developed in the case-law of the European Court of Justice.

The general principles of law could be divided into two main categories in accordance with inter alia Marcusson's classification: the first category consists of wide-ranging principles such as the principle of primacy of EU law and the principle of loyalty which govern the legal relationship between the EU and the Member States. The second category of the general principles is the principles relating to the application of substantive EU law and it could be called the material and procedural administrative principles such as the principle of proportionality and the principle of good administration [18].

According to Groussot, there are two types of administrative law principles: the first concerns the principles of material nature i.e. principles that apply to the material side of administrative procedures. These principles consist of proportionality, equal treatment and the principle of legal certainty and legitimacy of expectations. The second set of the administrative law principles is the principles of procedural nature; in other words, the principles relating to the process itself in an administrative procedure. These principles are the right to be heard, the right to effective judicial protection, the principles of good administration and openness (the principle of care, duty to act in a reasonable time) and the principle of access to documents [10]. However, Schwarze classifies proportionality and legal certainty and legitimate expectations as principles of administrative law in material nature, while the principle of care, the right to defense (including the right to be heard) and the obligation to state reason constitute administrative law principles of procedural nature [19].

The fact which would be crucial to be considered here is that the three concepts the general principles of law, fundamental rights and principles of good administration are overlapping in the administrative law area in a way that they

\footnotetext{
1 Treaty on European Union.

2 Treaty on the Functioning of the European Union.

${ }^{3}$ European Convention on Human Rights, 1950
}

form an integrated administrative law system in the EU law ${ }^{4}$. On the one hand, the EU Courts in a number of cases, such as Internationale Handelsgesellschaft Stauder [20], Nold [21], and Alborg [22] considered the fundamental rights as an integral part of the general principles of law [23]. On the other hand, the Court has widely construed the principle of good administration against the background of the general principles of law. According to Reichel, the intention of the Court to interpret the principle of good administration as general principle of law might be that the ECJ has considered the general principles of law as principles of a constitutional nature and they are considered to have the same high status as the Treaties' provisions [24], and consequently the Court perceptively afforded such high legal status to the principle of good administration. Finally, regarding the fundamental rights, both the Charter of Fundamental Rights (art.41) and the ECJ - as in the case Al-Jubail [25] - defined the principles of good administration as fundamental rights of individuals in their relationship with the authorities.

The compatibility and the disparity of these approaches would be interesting to be discussed in the light of both Caselaw and Charter of Fundamental rights as the two most important sources for arising and developing the principle of good administration in the EU law.

\section{GOOD ADMINISTRATION IN THE EU DOCUMENTS}

The principle of good administration, in accordance with article 41 of the Charter of Fundamental Rights, is a fundamental principle of law within the EU [26]. The legal roots of this principle in Europe stems from the European Convention in 1950 [27]. However, Resolution (77) 31 [28], issued by the Council of Europe was a significant step towards defining the principles of good administration though the concept of good administration is not explicitly included in the resolution. The resolution established certain fundamental principles and standards for the European countries in order to regulate the relationship between individuals and administrative authorities ${ }^{5}$. The Council of Europe also issued a handbook titled (The Administration and You) in which the common principles of good administration in the European countries clearly explained [14]. And lately a recommendation has been adopted by the council of Europe as a code of good administration in which the principles of good administration have been stated in more detail [29].

\footnotetext{
${ }^{4}$ It should be taken into account that the general principles of law and fundamental rights would usually be construed in a broader context so that they are considered to cover a comprehensive area, while the principles of good administration are limited to administrative law.

5 The Principles which had been stated in the resolution's appendix were right to be heard, the right to have access to information, the right to legal advice, the obligation to justify administrative decisions and finally the public authorities' duty to facilitate possibilities of individuals to appeal the decision.
} 
Regarding the European Union, it would be noteworthy to mention that the European Parliament in a recent resolution ${ }^{1}[30]$ has requested the Commission to submit a proposal of a regulation on a European Law of Administrative Procedures. In the detailed recommendations as to the content of the proposal requested, to be precise in the first recommendation, the European Parliament has set the objective of the requested regulation which is "to guarantee the right to good administration by means of an open, efficient and independent administration based on a European Law of Administrative Procedure" [30]. The resolution has afforded a set of administrative principles to be classified under the principles of good administration and to be codified in the requested regulation. ${ }^{2}$

Further, it can be alleged that a prominent development concerning defining the principles of good administration was when the European Ombudsman drafted the European Code of Good Administrative Behavior in 1999. ${ }^{3}$ In the Code, the principles of good administration in the EU institutions and bodies were defined. ${ }^{4}$ It would be noteworthy to point out that the Ombudsman's Code is not legally binding for the EU institutions and bodies [31] due to the non-legislative position of the Ombudsman inside the EU. The code might rather be deemed as a guideline for the Union's legislative and executive institutions and organs regarding the consideration of the principles of good administration. Further, as the Ombudsman states in a latter version of the code, elements of the code "overlap... with the fundamental right to good administration, which is enshrined in article 41 of the Charter of Fundamental Rights of the European Union" [31]. In some way, the Code might be deemed as a detailed account of the articles 41 and 42 of the Charter of Fundamental Rights of the European Union.

\footnotetext{
${ }^{1}$ The principles which have been mentioned in the recommendation to be defined as principles of good administration consist of principle of lawfulness, principle of equality, principle of impartiality, principle of proportionality, principle of legal certainty, principle of taking action within a reasonable time limit, principle of participation, principle of respect of privacy, principle of transparency. See articles 2-10.

2 The principles consist of; principle of lawfulness, principle of nondiscrimination and equal treatment, principle of proportionality, principle of impartiality, principle of consistency and legitimate expectations, principle of respect of privacy, principle of fairness, principle of transparency, principle of efficiency and service. See ibid. Recommendation 3 in the ANNEX.

${ }^{3}$ The code adopted by the European parliament in 2001.

${ }^{4}$ The principles according to the Code include: the principles concerning the material side of the administrative provisions, such as lawfulness, absence of discrimination, proportionality, absence of abuse of power, impartiality and independence, objectivity, legitimate expectations, consistency and advice, fairness, courtesy (Art. 4-12). The Code also contains the procedural rules of good administration such as reply to letters in the language of the citizen, acknowledgment of receipt and indication of the competent official, obligation to transfer to the competent service of the institution, the right to be heard and to make statements, reasonable time limit for taking decisions, duty to state grounds for decisions, indication to appeal possibilities, notification of the decision, data protection, requests for information, requests for public access to documents, keeping of adequate records (Art. 13-24).

However, the very eminent document in the concern of the principle of good administration is the Charter of Fundamental Rights of the European Union which is deemed to be a part of EU's secondary law after Lisbon. Below is a brief overview of this document.

\section{GOOD ADMINISTRATION IN THE CHARTER OF FUNDAMENTAL RIGHTS OF THE EUROPEAN UNION}

There is no doubt, the very genuine legislative step by the European Union relating to defining the principle of good administration was taken through the recognition of the individual rights to receive fair and appropriate administrative handling by the EU institutions. This right is established in article 41 of the Charter of Fundamental Rights of European Union enacted in 2000. However, it is noteworthy to point out that the Charter did not have binding force before the year 2009. Once the Lisbon Treaty entered into force in 2009, the Charter accordingly, based on article 6 TEU, became legally binding [32]. Notwithstanding that the principle(s) of good administration has been taken into account in the EU case-law prior to enacting the Charter; undoubtedly the latter seems to be a significant document in the concern of recognizing the principles of good administration. The Charter is also considered as the first charter of the fundamental rights at the international level which has explicitly documented the principle of good administration as covering subjective procedural rights [33]. And this, further, would play a tremendously prominent role in the future codification of administrative procedural rules in Europe [34].

As mentioned, the principles of good administration have been codified in article 41 of the Charter under the title right to good administration. The first paragraph of article 41 of the Charter emphasizes every person's right "to have his or her affairs handled impartially, fairly and within a reasonable time by the institutions and bodies of the Union" [35]. And the second paragraph of the same article is stating explicitly the principles of good administration in the form of right which includes [35]:

- the right of every person to be heard, before any individual measure which would affect him or her adversely is taken;

- the right of every person to have access to his or her file, while respecting the legitimate interests of confidentiality and of professional and business secrecy;

- the obligation of the administration to give reasons for its decisions.

In the third paragraph every person's right of compensation has been guaranteed against any EU institution or its servants if their actions cause any damage. Finally, the fourth paragraph of article 41 assures every person's right to write to EU institution in one of the languages of the Treaties, besides his/ her right to have an answer in the same language. 


\section{GOOD ADMINISTRATION IN THE EU COURTS' CASE-LAW}

European Union Courts have had a prominent role in defining and recognizing the principle of good administration in EU. However, the terminology is not necessarily the same in all case-law. Besides using of the wording good administration [36] and proper administration [37], EU courts have mostly uttered the term sound administration[38] in related cases. EU courts have begun to express and apply principle(s) of good administration in their legal assessments and judgments from the start of the European Community. It seems likely that it is the lack of a concrete Community administrative statute in the EU in the first place, and secondly the lack of consensus regarding the principles of good administration within the EU institutions and the Member States, which prompted the Community Courts to recognize, on their own, some of the most essential principles of their judgments. Nonetheless, there is no consensus regarding the definition of the concepts of good, proper or sound administration in the matter of which principles of law could be - or could not be - classified under the concept of good administration. What might be well observed is that the principle of good administration in the perspective of EU caselaw is mainly limited to the procedural rights/principles which would arise in an administrative process. ${ }^{1}$

On closer observation of EU case-law, it could be argued that the principle of good administration is considered to be an indispensable procedural requirement which is essentially related to the principle of care or due diligence. [39] Even though the principle of care is unarguably considered as a part of the umbrella which constitutes the principle of good administration, the EU courts have used these two concepts overlapping with each other in a number of cases giving an impression of confusion in the use of the concepts [40].

Although in other cases the EU courts have not uttered the word good administration but considered the principle of care, it could be understood that the good administration has been taken into consideration partly through invoking the principle of care. Case Nölle II in 1995 is illustrative in that regard, in which the principle of care is recognized as a subjective right which can be invoked by individuals against administrative authorities $^{2}$ [41]. Even in the case Nölle I the Court had recognized the principle of care as a general principle of

\footnotetext{
${ }^{1}$ This statement should not be understood in the way that the EU courts omit the substance of the cases and only take in to consideration the processbased values at the expense of the material side of the cases. This limitation is, rather, only applied to the concern of principles of good administration.

${ }^{2}$ The Court stated "The Court notes that, according to the case-law of the Court of Justice, where the Community institutions have a wide power of appraisal, respect for the rights guaranteed by the Community legal order in administrative procedures is of even more fundamental importance. Those guarantees include, in particular, the duty of the competent institution to examine carefully and impartially all the relevant aspects of the individual case...".see the referred case, para. 73 .

Community law $^{3}$ [42]. The Court, in Nölle I, cancelled the Commission's decision on the duties imposed on the company Nölle, and annulled at the same time the Council's regulation that had been alleged in the case. The reason for that decision was that the Commission and the Council had not taken appropriate action in their executive and legislative conducts, even though the corporation had provided sufficient information to substantiate its assertion in its claim. The Commission and the Council, therefore, according to the Court, failed to fulfill their investigative responsibilities [43]. It is noteworthy to call attention to the fact that the Court in Nölle I did not go into the discussion of the material subject of the dispute when it annulled the Commission's decision. Rather, the Court only took into account that the Commission had not carefully taken steps in the matter ${ }^{4}$. In other words, the violation of the principle of care that was made by the Commission has played a decisive role in the case, regardless of the outcomes of the Commission's decision ${ }^{5}$.

Another important procedural principle which is invoked frequently in EU case-law is the right to be heard. Already in 1963, during the European Coal and Steel Community's time, the right to be heard was recognized as an administrative requirement which originated from the then- member states' administrative law. In the case Alvis [44], the Court found that the right to be heard is a general principle in the Community. The case concerned an official who had been dismissed without being given an opportunity to be heard. The Court held that the Community institutions must afford their employees the opportunity to answer the allegations before any administrative decision is taken against them [45]. However, from the beginning of the European Community, the jurisdiction of the Community courts in the matter of treating the right to be heard was limited to competition law. Competition law thus became the starting point for applying

\footnotetext{
${ }^{3}$ The case concerned a dispute between the corporation Nölle and the Commission on establishing a reference country in order to determine the normal value of the goods imported by the company. Nölle had claimed that the Commission's decision to impose anti-dumping customs on its imports from China, which had been taken, based on the Council's anti-dumping regulation, is unlawful. In the decision, the Commission had chosen Sri Lanka as the reference country for determining the normal value of the imported goods, despite the fact that Nölle had argued that Taiwan was an appropriate reference country other than Sri Lanka. In its review, the Court ruled that the Commission and the Council had not taken sufficient steps to investigate whether Taiwan could be considered a more appropriate reference country that Nölle had argued and even provided sufficient information to prove their claim. The Court accordingly annulled both the Commission's decision and the Council's regulation on the ground that the institutions had failed in its investigative responsibilities.

${ }^{4}$ The Court grounded its decision on Article 2 (5) (a) of the basic antidumping regulation, and stated in its judgment: "In these circumstances it must be considered that the normal value was not determined 'in an appropriate and not unreasonable manner' within the meaning of Article 2 (5) (a) of the basic regulation." See the referred case, para. 38 .

${ }^{5}$ Although the Court has not mentioned the principle of due diligence explicitly in its judgment, the court's judgment and arguments could strongly be interpreted in the light of the principle of care (due diligence). However, the Court has mentioned the principle of due diligence in Nölle II from the year 1994 when Nölle's compensation claim was investigated.
} 
the principle [13]. The EU courts afterwards extended this jurisdiction so that the principle could be applied in other legal spheres. In the case Transocean Marine Paint Association[46] (1974), the ECJ recognized the right to be heard as a general principle of the EU law [47]. In this case, the ECJ reviewed a competition law decision by the Commission which had adversely affected the association Transocean Marine Paint without giving an opportunity to the Association to comment on the matter. The Court ruled that the right of individuals to be heard was a general regulation and it should be protected even if this had not been granted in the secondary Community legislation [48].

However, in the two cases, Hoffmann (1979) [49] and AlJubail (1991)[50], the EU Court acknowledged the right to be heard as a fundamental right in the European Union -formerly European Community- which is deemed as an integral part of the general principles of law [51].

Regarding the other renowned procedural principle, namely the obligation to state reason for the administrative decisions by the union's authorities and organs, the EU courts have taken into consideration observance of the principle by the EU institutions in accordance with Art.263 TFEU. $1^{2}$ Failure to state reason for the administrative decisions would consequently be considered as an infringement of an essential procedural requirement. Therefore, such an infringement can lead to the annulment of administrative decisions as being insufficiently reasoned according to Art. 263. An illustrative case-law in that regard is the case 24/62 Germany v Commission [52]. The case concerned a Commission's decision in which the Commission had rejected an application from the German government to import a large amount of wine. European Court of Justice annulled the Commission's decision on the ground that the statement of reasons for the decision was deficient [52]. Moreover, in the joined cases SLM \& Ori Martin in 2015, the Court rejected to differentiate between the principle of good administration and the obligation to state reason [53].

Finally, it would not be irrelevant to mention that in the very well-recognized case TU München (1991), the importance of the obligation to state reason was underlined in association with the other two principles i.e. the principle of care and the right to be heard. These three procedural principles have been stated in TU München as guarantees which must be provided in the administrative procedures [54].

\section{GOOD ADMINISTRATION; FUNDAMENTAL RIGHT OR ADMINISTRATIVE STANDARD?}

In the lack of a common administrative act in EU, the administrative procedural rules can be found in the EU's primary and secondary law. Regarding the Charter of
Fundamental Rights as a secondary law and a significant legally binding document, the picture is unblemished in the sense that the Charter has interpreted the important procedural rules like due diligence, right to be heard and duty to state reason as- and against background of- a fundamental right under the title right to good administration in art.41. However, the case-law of the European Court of Justice would still be considered as a main source for the administrative procedural rules inside EU. The Courts has through case law developed administrative procedural rules in the form of general principles of law. Even from individual rights' perspective, it can be said that individual rights are also to be protected by the EU courts in the form of general principles of law [55]. Consequently, the concept good administration in EU courts' case-law has been mostly understood as a general principle of law which represents in itself an objective principle. However, it may, in some grade, confer even subjective rights through its sub-principles [56].

Based on a specific approach in the light of the EU courts' case-law regarding understanding the natures of the principle of good administration, there is a trend for differentiating the characteristic of the three procedural sub-component of the principle of good administration in the sense that the principle of care and the obligation to state reason would merely be deemed as 'process standard' for the EU institutions, while the right to be heard obviously constitutes a subjective right which aims to protect individuals' interest during a specific administrative process [57, 58]. Consistent with this approach, the European Court of Justice has in, inter alia, the case Kuhner interpreted the right to be heard against the background of the general principle of good administration [59].

It might not be irrelevant to point out that the 'standard or requirement' characteristic of the procedural principles, inter alia, the principle of good administration is to be significant in the matter of judicial review of the administrative conducts of the EU institutions, in occasions when the Court reviews an administrative proceeding and has a margin of discretion. This margin of discretion can be reasonable only if the discretion is applied under the commitment to procedural requirements by the EU institutions in the form of the principles of good administration [60]. In other words, within some legal systems the principle of good administration is considered as a fundamental right of individuals according to which an individual can plea an incorrect handling of an administrative authority, even if the outcome of the case is not affected by this faulty handling. While in other legal systems, the principle would rather be deemed as an instruction to the administrative authorities to facilitate the handling of administrative matters in a satisfactory way [61].

However, the principle of good administration should not necessarily be thought of unilaterally; the principle can rather 
be interpreted from both sides. Similarly Reichel articulates that there would not essentially be any conflict between the two views; good administration might seem to be an obligation of the authorities and it can be simultaneously perceived as a right for individuals in their relationship with the authorities [61]. Nevertheless, the modern approaches in the matter of human- and individual rights have led to the fact that the focus has been shifted from the 'standard- rules' to the subject of the fundamental rights for human being as a central issue, and consequently, the individual rights in general have been topical in the legislative and executive manner. Therefore, the procedural rules have gained unproblematic understanding and acceptance as individual rights.

Although in case-law the "process standards" tendency is to be found in that sense when the EU courts examine whether the EU institutions have taken appropriate procedural measures in their administrative conduct in every single case, this can teleologically be construed against the background of the protection of the fundamental individual rights which have been recognized in the EU's- and international documents. In other words, even though the EU Courts have, and not such rarely, underlined that 'the general principle of good administration' does not confer individual rights in itself [62], the principle of good administration could not be divested from the fundamental rights established in the modern societies' legal systems especially when it be examined in its sub-component principles.

\section{CONCLUSION}

In general, good administration as an umbrella-principle might be deemed as an instrument for enhancing transparency, legal certainty and predictability in administrative procedures [60].

There is, however, no certain definition for the principle. The definitions differ depending on the disparity of the viewpoints. Whether the principle constitutes fundamental right(s) for individuals or it is compulsory administrative requirement(s) imposed on public authorities in EU during the administrative proceedings. The Charter of Fundamental Rights of the European Union is a prominent legislative document in the Union since the commencement of Lisbon Treaty- era. The Charter has determined its attitude concerning the characteristic of the principle of good administration by defining it as a fundamental right of individuals which indisputably must be observed and protected by the administrative authorities when proceeding administrative cases of individuals. The issue might, however, be different in the context of case law of the EU courts. The Courts have, since the beginning of the European Community, observed the principle(s) though in the form of general principles of law.
The perception of the principle of good administration by the EU Courts through case law can be understood in a manner that the Courts have differentiated between the comprehension of the sub-component of the principle in a sense that two of the sub-principles i.e. the principle of care and the obligation to state reason are most likely constitute administrative standards for the EU institution during the handling of administrative cases, while the right to be heard confer a procedural right for individuals in their contact with the Union's institution. These two different perspectives are, however, not necessarily be understood in a contentious manner. Good administration can be understood as fundamental right(s) which should be safeguarded and at the same time it might work as an instrument for measuring the legality of the institutions' administrative decisions and conducts. This paper suggests, however, that understanding the issue from the perspective of the notion of the fundamental rights can establish stronger and stricter rules in the manner that the individual rights have been in the center in the modern administrative systems around the globe and have been protected by essential European and international documents. Consequently, the tendency of seeing the principle of good administration as fundamental right(s) can more rationally be adopted in order to confer a more forceful protection for individuals by compelling the Union's institutions to observe and respect the principle in the form of fundamental rights of individuals.

\section{REFERENCES}

[1] L. Marcusson, "» Den goda förvaltningen-en mänsklig rättighet i välfärdsstaten?«," Nordisk Administrativt Tidsskrift, vol. 89, pp. 97-107, p. $98,2012$.

[2] I. Koprić, A. Musa, and G. Lalić Novak, "Good administration as a ticket to the European administrative space," Zbornik Pravnog fakulteta u Zagrebu, vol. 61, pp. 1515-1560, 2011.

[3] V. Negrut, "Europeanization of Public Administration through the General Principles of Good Administration, The," Acta U. Danubius Jur., pp. 5- 15, p. 6, 2011.

[4] J. Reichel, "Europeiska principer för god förvaltning," in Offentligrättsliga principer. vol. 2, L. Marcusson, Ed., ed Uppsala: Iustus förlag, 2012, p. 50.

[5] L. Marcusson, "» Den goda förvaltningen-en mänsklig rättighet i välfärdsstaten?«," Nordisk Administrativt Tidsskrift, vol. 89, pp. 97-107, p. 100, 2012.

[6] H. P. Nehl, "Good administration as procedural right and/or general principle," Legal Challenges in EU Administrative Law: Towards an Integrated Administration, Edward Elgar Publishing Limited, UK, pp. 322-354, p. 338, 2009.

[7] (Nov. 16). MODERNISING ADMINISTRATIVE PROCEDURES, MEETING EU STANDARDS. Available: http://www.respaweb.eu/download/doc/Modernising+Administrative+Pr ocedured+Meeting+EU+Standards.pdf/abba43c63e77c186dfb4e18fd5b5 00cf.pdf

[8] J. Hettne and I. Otken Eriksson, EU-rättslig metod-Teori och genomslag i svensk rättstillämpning: Norstedts juridik, 2011.

[9] J. Reichel, God förvaltning i EU och i Sverige. Stockholm: Jure, 2006. 
[10] X. Groussot, Creation, Development and Impact of the General Principles of Community Law: Towards a jus commune europaeum?: Lund University, 2005.

[11] A. Lenaerts and Maselis, Procedural Law of the European Uinon. London: Sweet \& Maxwell, 2006.

[12] J. Reichel, God förvaltning i EU och i Sverige. Stockholm: Jure, 2006.

[13] D. Chalmers and A. Tomkins, European Union Public Law, 2007.

[14] J. Reichel, God förvaltning i EU och i Sverige. Stockholm: Jure, 2006.

[15] V. Negrut, "Europeanization of Public Administration through the General Principles of Good Administration, The," Acta U. Danubius Jur., pp. 5-15, p. 10, 2011.

[16] "Case 222/86, Union nationale des entraîneurs et cadres techniques professionnels du Football (UNECTEF) v Georges Heylens and Others [1987] ECR 04097, para. 15. ," ed.

[17] J. Hettne, Rättsprinciper som styrmedel: allmänna rättsprinciper i EU: $s$ domstol. Stockholm: Norstedts Juridik, 2008.

[18] L. Marcusson, "Principer inom den offentliga rätten," in Offentligrättsliga principer, L. Marcusson, Ed., ed, 2012, p. 11.

[19] J. Shwarze, European Administrative Law. London: Sweet\& Maxwell, 2006.

[20] Case 11/70 Internationale Handelsgesellschaft mbH v Einfuhr- und Vorratsstelle für Getreide und Futtermittel [1970] of 17/1271970.

[21] Case 4/73 Nold KG v Commission [1074] ECR 00491.

[22] Joined Cases C-204/00 P, C-205/00 P, C-211/00 P, C-213/00 P, C217/00 P and C-219/00 P, Aalborg Portland \& Others v Commission [2004] ECR I-00123.

[23] H.-J. Blanke, "The Protection of Fundamental Rights in Europe," in The European Union after Lisbon, Constitutional Basis, Economic Order and External Action, H.-J. M. Blanke, Stelio, Ed., ed Berlin -Heidelberg: Springer- Verlag, 2012, pp. 159-232.

[24] J. Reichel, "Europeiska principer för god förvaltning," in Offentligrättsliga principer. vol. 2, L. Marcusson, Ed., ed Uppsala: Iustus förlag, 2012, p. 54.

[25] Case C-49/88 Al-Jubail Fertilizer Company (Samad) and Saudi Arabian Fertilizer Company (Safco) v. Council [1991] ECR I-3187, para. 15.

[26] I. Cuculoska, "The Right to Good Administration of the EU: Definition, Scope and Content," Iustinianus Primus Law Review, vol. 5.2, pp. 1-22, p. 19, 2014.

[27] L. Marcusson, "God förvaltning-en rättslig princip?," in God förvaltning - Ideal och praktik, L. Marcusson, Ed., ed Uppsala: Isutus förlag, 2006, p. 9.

[28] Resolution (77) 31 of the Protection of the Individual in Relation to the Acts of Administrative Authorities, C. o. M. the Council of Europe, 1977.

[29] Recommendation CM/Rec (2007)7 of the Committee of Ministers to Member States on Good Administration (Adopted by the Committee of Ministers on 20 June 2007 at the 999bis meeting of the Ministers' Deputies).

[30] European Parliament Resolution of 15 January 2013 with Recommendations to the Commission on a Law of Administrative Procedure of the European Union (2012/2024 (INL)).

[31] The European Code of Good Administrative Behavior t. E. Ombudsman, 1999.

[32] " THE TREATY ON EUROPEAN UNIONEN," ed. European Union: CONSOLIDATED VERSION OF THE TREATY ON EUROPEAN UNIONEN.

[33] H. C. Hofmann and C. Mihaescu, "The Relation between the Charter's Fundamental Rights and the Unwritten General Principles of EU Law: Good Administration as the Test Case," European Constitutional Law Review, vol. 9, pp. 73-101, p. 86, 2013.

[34] J. P. Solé, "EU Law, Global Law and the Right to Good Administration," in Global Administrative Law and EU Administrative Law, ed: Springer, 2011, pp. 133-145, p. 140.

[35] CHARTER OF FUNDAMENTAL RIGHTS OF THE EUROPEAN UNION," ed. European Union, 2000.

[36] See eg Case 32/62 Maurice Alvis v Council [1963] ECR 49, at para. 1; Case 64/82 Tradax Graanhandel BV v. Commission [1984] ECR 1359, at pp.1366, 1367, 1369, 1370, 1372, 1376, 1377 and 1379; Case 223/85 Rijn-Schelde-Verolme (RSV) Machinefabrieken en Scheepswerven NV v Commission[1987] ECR 4617, at paras. 7 and 12; Case T-83/91 Tetra Pak International SA v Commission [1994] ECR II-755, at paras. 24, 27, 28, 30, 31 and 230; Case T-209/01 Honeywell International Inc. V Commission [2005] ECR II-05527, at para. 47; Joined Cases T-458/09 and T-171/10 Slovak Telekom a.s v Commission [2012] ECR nyr of 22/3/2012, at paras. 65, 67, 68 and 69; Case T-286/09 Intel Corp v Commission [2014] ECR nyr of 12/6/2014, at paras. 619, 621 and 626;
Joined Cases T-413/10 and T-414/10 Socitrel - Sociedade Industrial de Trefilaria, SA and Companhia Previdente - Sociedade de Controle de Participações Financeiras, SA v Commission [2015] ECR nyr of $15 / 7 / 2015$ at para. 370 and 416 .

[37] See eg Case 178/80 Amedeo Bellardi-Ricci and others v Commission [1981] ECR 03187, at para. II, p. 3191; Case 64/82 Tradax Graanhandel BV v. Commission [1984] ECR 1359, at p.1372; Case T-167/94 Detlef Nölle v Council and Commission [1995] ECR II-02589, at paras. 53, 61, 67, 69, 77, 79, 88 and 89; Case T-209/01 Honeywell International Inc. v Commission [2005] ECR II-05527, at paras. 56 and 66; Case T-299/08 Elf Aquitaine SA v Commission [2011] ECR II-02149, at para. 242.

[38] See, eg Case T-196/99 Aera Cova and Others v Council and Commission [2001] ECR II-03597, at paras. 22, 28, 38 and 43; Case T15/02 BASF AG v Commission [2006] ERC II-00497, at paras. 30, 472, 501, 502, 526, 590, 591, 592, 593 and 604; Case T-193/04 Tillack v Commission [2006] ECR II-03995, at paras. 89, 101, 106 and 127; Case T-66/01 Imperial Chemical Industries v Commission [2010] ECR II02631, at paras. 196 and 233; Joined Cases T-394/08, T-408/08, T453/08 and T-454/08 Regione autonoma della Sardegna and Others v Commission [2011] ECR II-06255, at paras. 72, 99 and 158; Case T299/08 Elf Aquitaine SA v Commission [2011] ECR II-02149, at paras. 33, 232, 234, 235, 238, 240 and 241; Case T-297/11 Buzzi Unicem SpA v Commission [2014] ECR nyr of 14/03/2014, at paras. 18, 137, 142, 143, 144, 147 and 148; Case T-286/09 Intel Corp v Commission [2014] ECR nyr of 12/6/2014, at paras. 359 and 365; Case T-436/10 HIT Groep v Commission [2015] ECR nyr of 15/7/2015, at paras. 165, 172 and 187; Joined Cases T-413/10 and T-414/10 Socitrel - Sociedade Industrial de Trefilaria, SA and Companhia Previdente - Sociedade de Controle de Participações Financeiras, SA v Commission [2015] ECR nyr of 15/7/2015, at para. 187; Case C-61/14 Orizzonte Salute — Studio Infermieristico Associato v Azienda Pubblica di Servizi alla persona San Valentino - Città di Levico Terme and Others [2015] ECR nyr of 6/10/2015, at paras. 37 and 40.

[39] H. P. Nehl, "Good Administration as Procedural Right and/or General Principle?," in Legal Challenges in EU Administrative Law, Hoffman and Türk, Eds., ed: Edward Elgar, 2009, p. 334.

[40] See eg., Case T-167/94 Nölle v. Council and Commission [1995], ECR II-2589, at paras. 53, 67,77,79 and 89; Case C-248/99 P French Republic v Monsanto Company and Commission [2002] ECR I-00001, at paras. 92-93; Case T-88/13 P, Z v Court of Justice of the European Union [2015] ERC nyr of 19/6/2015, at para. 28.

[41] Case T-167/94 Nölle v Council and Commission [1995] ECR II-2589.

[42] Case C-16/90 Detlef Nölle v Hauptzollamt Bremen-Freihafen [1991] ECR I-05163.

[43] Case C-16/90 Detlef Nölle v Hauptzollamt Bremen-Freihafen [1991] ECR I-05163 at paras. 23-38.

[44] Case 32/62 Maurice Alvis v Council [1963] ECR 49.

[45] Case 32/62 Maurice Alvis v Council [1963] ECR 49 at para. 1.

[46] Case 17/74 Transocean Marine Paint Association v. Commission [1974] ECR 1063.

[47] J. Schwarze, European Administrative Law. London: Sweet\& Maxwell, 2006.

[48] Case 17/74 Transocean Marine Paint Association, para. 15.

[49] Case 85/76 Hoffmann-La Roche \& Co. AG v. Commission [1979] ECR.

[50] Case C-49/88 Al-Jubail Fertilizer Company (Samad) and Saudi Arabian Fertilizer Company (Safco) v. Council [1991] ECR I-3187.

[51] See Case 85/76 Hoffmann, para. 9 and Case C-49/88, Al-Jubail, para. 1.

[52] "Case 24/62 Germany v Commission [1963] ECR English edition 1963.

[53] Joined cases T-389/10 and T-419/10 Siderurgica Latina Martin SpA (SLM) \& Ori Martin v Commission [2015] ECR nyr of 15/7/2015, para. 416.

[54] Case C-269/90 Technische Universität München v Hauptzollamt München-Mitte [1991] ECR I-5469, para.15.

[55] E. Nanopoulos, "European Human Rights Law and the Normalisation of the 'Closed Material Procedure': Limit or Source?," The Modern Law Review, vol. 78, pp. 913-944, 2015.

[56] M. De Leeuw, "The European Ombudsman's Role as a Developer of Norms of Good Administration'(2011)," European Public Law, vol. 17, pp. 349-368, p.355.

[57] H. P. Nehl, "Good administration as procedural right and/or general principle?," in Legal Challenges in EU Administrative Law, Hoffman and Türk, Eds., ed, 2009, p. 349.

[58] H. C. Hofmann and C. Mihaescu, "The Relation between the Charter's Fundamental Rights and the Unwritten General Principles of EU Law: 
JUHD / Vol. 3, No.1, March 2017: pp 259-267

Good Administration as the Test Case," European Constitutional Law Review, vol. 9, pp. 73-101, p. 90, 2013.

[59] See joined cases 33/79 and 75/79 Kuhner v. Commission [1980] ECR 1677, para. 25.

[60] J. Reichel, "Between Supremacy and Autonomy - Applying the Principle of Good Administration in the Member States," in General Principles of EC Law in a Process of Development, U. Bernitz, J. Nergelius, and C. Cardner, Eds., ed: Kluwer Law International B.V. , 2008, pp. 243-271. p. 254.

[61] J. Reichel, "God förvaltning i EU och i Sverige," p. p. 258 and 561, 2006.

[62] See eg Case T-193/04 Tillack v Commission, para. 127 and Case T196/99 Area Cova and Others v Council and Commission, para. 43. 